\title{
Strategy to Increase Work Productivity Among Millennial Generation
}

\author{
Yeni Nuraeni ${ }^{1}$, Faizal Amir P Nasution ${ }^{2}$ \\ yeninur@hotmail.com ${ }^{1}$, faiz10march@gmail.com ${ }^{2}$ \\ Center for Policy Development of the Ministry of Manpower of the Republic of Indonesia ${ }^{1,2}$ \\ Jl. Gatotsubroto Kav 51 Jakarta
}

\begin{abstract}
Millennial generation workers generally have different characteristics, where they tend to prefer flexibility and use digital technology in their work. Companies must have a strategy to increase workers' productivity from the millennial generation so that their superiority in using technology can provide benefits for increasing company productivity. This study aims to evaluate and analyze the work culture of the millennial generation and formulate a strategy to increase the work productivity of the millennial generation so that it can increase the nation's competitiveness. The data analysis used in this study is a qualitative method. Primary data collection was carried out through in-depth interviews with respondents from the company's management and workers, the majority of whom came from the millennial generation. The results show that companies implement several strategies to increase the productivity of the millennial generation, including providing a platform for them to express their aspirations; companies must be able to bridge communication and coordination between the millennial generation and previous generations so that harmonious relationships can be created, the application of discipline and transfer programs knowledge in the internal company.
\end{abstract}

Keywords: Work Productivity, Millennial Generation, Productive Work Culture

\section{Introduction}

\section{Millennial Generation and the WorkForce in Indonesia}

Indonesia will enter the era of demographic bonus, marked by a decrease in the dependency ratio, which will reach its lowest point in the 2019-2024 period when the dependency ratio comes around 45,4\%. [1]. This condition will have an indirect impact on increasing labor supply, saving, and human capital and followed by reduced costs for meeting the needs of the population of unproductive age so that there are opportunities to achieve more significant economic benefits by diverting existing resources to increase growth the economy and welfare of the people. According to the Indonesian National Family Planning Agency (Badan Keluarga Berencana Nasional / BKKBN), Indonesia will have a demographic bonus between 2020-2030; at that time, the age of the workforce 15-64 years old reaches 70\%, while the remaining $30 \%$ is an unproductive population. (Indonesian Ministry of Women's Empowerment and Child Protection \& Indonesian Central Bureau of Statistics, 2018).

The demographic bonus will not be separated from the millennial generation, wherein in 2017 , the proportion of the millennial generation will reach $33,75 \%$ of the total Indonesian 
population [1]. Millennials are the largest workforce in Indonesia. The development of the millennial generation in the force in Indonesia, according to data obtained from the Thematic Gender Statistics, shows that around $50,36 \%$ of the total population of productive age are millennials. [2]. Based on the Central Statistics Agency data in 2016, the entire workforce in Indonesia is 120.647 .697 , of which 46.847 .228 or $38.83 \%$ belong to the millennial generation [3]. In 2020, the millennial generation was projected to be the generation that dominates the world of work [4].

The entry of the millennial generation into the Indonesian labor market will undoubtedly bring about a transformation from an economic, political, social, and cultural perspective. Along with the new era in the industrial revolution 4.0, the millennial generation is expected to become a productive and competitive workforce to face significant changes. Digitalization has penetrated all aspects of life and has brought changes in people's lifestyles. The millennial generation is expected to be prepared and able to respond to any changes, seize opportunities, and optimize the moments created due to the faster circulation of information and technology. [5]. The millennial generation will take control of the wheels of economic development and become a significant capital for nation-building so that they are expected to have superior potential compared to previous generations.

\section{Differences in Generational Values in the World of Work}

Standard and widely used criteria for distinguishing generations are the years of birth and events occurring globally [6]. There are 6 generation groups based on the year of delivery, as shown in table 1.

Table 1. Generation Difference

\begin{tabular}{|c|c|}
\hline Year of Birth & Generation Name \\
\hline $1925-1946$ & Veteran Generation \\
\hline $1946-1960$ & Baby boom generation \\
\hline $1960-1980$ & X Generation \\
\hline $1980-1995$ & Y Generation \\
\hline $1995-2010$ & Z Generation \\
\hline $2010+$ & Alfa Generation \\
\hline
\end{tabular}

Source : (A. Bencsik, C. G. abriella Horváth, and T. Juhász, 2016) [7]

Generational values are studied in two categories by an individual character: year formation, style, views on money, leisure, technology, and views on work, including career, recognition and rewards, leadership, and authority. [8]. Each generation has different characteristics of work behavior [9]. In the world of work, baby boomers are hardworking, optimistic, and loyal, appreciate teamwork, and see work from a process-oriented perspective. Generation X was born between 1965 - 1980. In the workplace, this generation is skeptical of authority and favors independent leaders. This generation can collaborate and be separate, more generous, skilled in management, financially intelligent, independent, not intimidated by police, and innovative [10]. Generation $X$ values more autonomy and independence and views work from an action-oriented perspective [11]. Generation $\mathrm{Y}$ is known as a generation with high expectations of work and achievement-oriented [12].

Generation X and Generation Y have a completely different view of the world of work 
than the traditional baby boomers [13]. Generations of baby boomers, $\mathrm{X}$ and $\mathrm{Y}$, differ in terms of demands, expectations, values, and ways of working. In addition, it can also be seen that for generations $\mathrm{X}$ and $\mathrm{Y}$, goal orientation and work environment affect satisfaction and intention to remain part of the organization. At the same time, baby boomers derive pleasure from relationship compatibility [9]. Work values are more influenced by generational experience than age and maturity [14]. Generations $\mathrm{X}$ and $\mathrm{Y}$ are more independent, while baby boomers enjoy power and position as decision-making authority [9].

Differences between the baby boomer generations, $\mathrm{X}$ and $\mathrm{Y}$, were also found in values related to compliance, work-life balance, and influence. Differences in generational values in the workplace are unavoidable. Still, they need to be appropriately managed to synergize and trigger creativity and innovation in working with multiple generations to achieve company goals [15]. It is a challenge for companies that currently have employees from these three generations in managing and directing the three generations to remain committed and show performance as desired by the company. [16].

\section{Portrait of the Millennial Generation in the World of Work}

Millennials are born between 1980-2000 and are the only generation who passed the second millennium [17]. The millennial generation is also often referred to as the $\mathrm{Y}$ generation. There are many popular terms about this generation; connected or digital generation atau gen, identical to courageous, innovative, creative, and modern characters [18]. Generation $\mathrm{Y}$ is a generation that has experienced changes in economic and technological conditions [19]. As the millennial generation, Generation $\mathrm{Y}$ is more tolerant of race, religion, culture, sexual orientation, and financial status than the previous generation [20]. Because Generation Y has grown and developed in a more diverse society, they have shown a willingness to embrace and accept cultural differences [21]

Generation $\mathrm{Y}$ is a group that gradually dominates the workforce and has a work result orientation and is called the internet generation with fast-moving, impatient, creative, and demanding characters [22]. Millennials have different work patterns from previous generations, such as "Generation X" or "Baby Boomers." In the workforce, $90 \%$ of Generation Y wants a job that offers flexible work schedules, demands creativity, and allows them to impact the world [23]. Millennials prefer to work flexibly to achieve a "work-life balance" [24]. Millennial workers who can balance work and life will have better job satisfaction than those who are not [25]. The characteristics of the millennial generation in the world of work can be seen in Figure 1. 


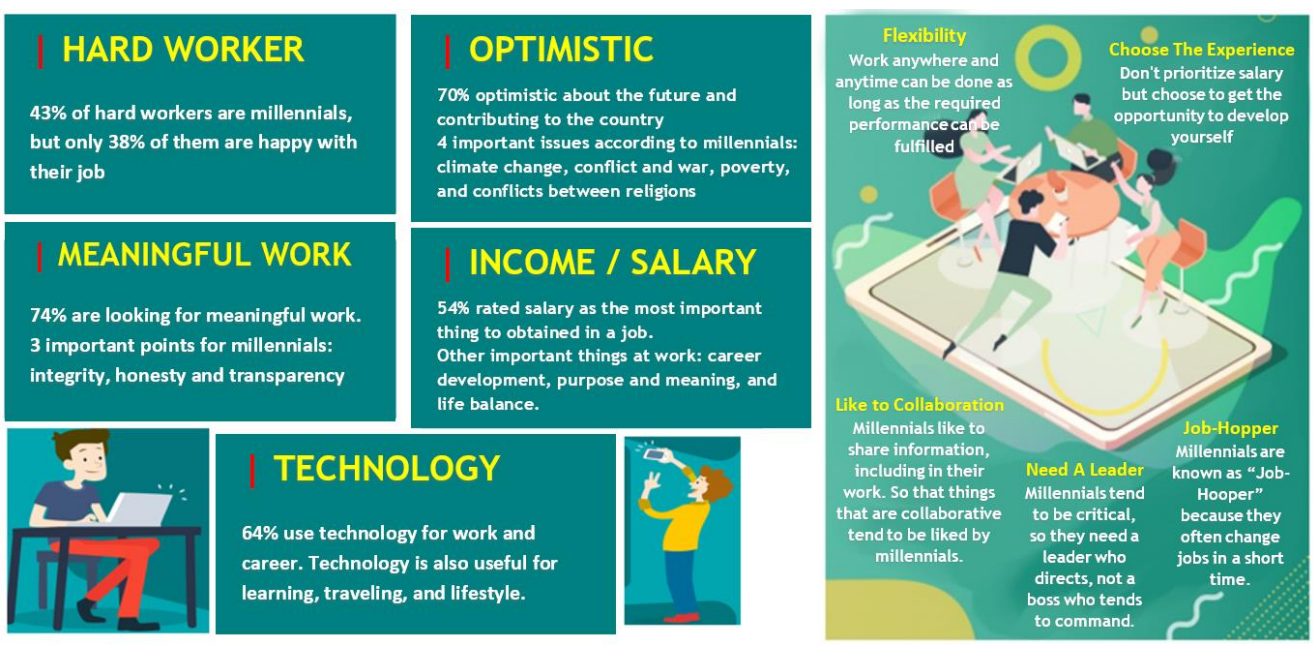

Figure 1. A Portrait of the Characteristics of the Millennial Generation in the World of Work Sources : [24], [26]

The proportion of the millennial generation that continues to increase from year to year allows in 2020 to reach $46 \%$ of the millennial generation, which dominates the world of work [27]. Based on research discussed at WEF, $43 \%$ of those called hard workers are millennials, while the other $57 \%$ percents are Generation X and Baby Boomers; millennials use technology, especially in their work and careers [26]. Generation Y grew up in the era of technology; they became proficient in accessing information quickly using technology [28], which became a fundamental reason for organizations to understand the nature, preferences, and behavior of generations [29]. Generation Y's career growth is more progressive than the baby boomers and generation $X[30]$.

Currently, the Millennial Generation is often in the spotlight in Human Resources (HR) management because they tend to have lower organizational commitment than the previous generation [31]. It is time for the company's HR management to realize and pay attention to the generational differences in their work environment, so it is necessary to determine the appropriate intervention for each generation. [32]. HR management must consider choosing a different approach to increase organizational commitment to each generation, especially the Millennial generation.

There have been many studies related to the characteristics of millennial workers and the values they hold in the world of work. This study aims to deepen what efforts have been made by company management to increase productivity in companies where most workers come from the millennial generation. The sample taken in this study is focused on companies that have won productivity awards and companies that already have productivity improvement units. By taking samples from companies that have proven to be successful in increasing their productivity, it is hoped that a recommendation can be obtained for other companies, what efforts can be made to increase work productivity among millennial workers. 


\section{Research Methods}

The method used in this study is a sampling method with a descriptive qualitative data analysis approach. This sampling method aims to get an overview of the values believed by the company's management in increasing its productivity through increasing the work productivity of its employees, most of whom come from the millennial generation.

The samples taken in the study used a purposive sampling technique. The sampling criteria are companies that have won awards in productivity from the government through staffing and companies that already have a productivity improvement unit. Companies taken include small, medium, and large companies and spread across five provinces in Indonesia. The total number of companies taken as samples is eight companies. Primary data collection was obtained through in-depth interviews and Focus group discussion (FGD). Respondents in this study are the company management and company employees.

Another uniqueness in this study is that researchers want to examine the factors that influence the company's success in handling employees from millennial circles to achieve achievements in increasing productivity by using qualitative analysis. At the same time, some previous studies have examined the factors that affect workers' performance in the millennial generation in a company using quantitative analysis.

\section{Result and Discussion}

\section{Democracy and Flexibility at Work}

Companies that employ most of their employees from the millennial circle adopt the organizational culture to uphold "World place democracy." Democracy is applied to every element of the company, they have the same voice, and they do not separate the rights of permanent and non-permanent workers. The company implements a democratic system because it realizes that what workers like among millennials is openness. A strong organizational culture, one of which is a democratic culture, will further improve the performance of millennial generation workers to be better and willing to work with colleagues, become a solid team at work so that the company's goals can be achieved [33].

One of the democratic systems implemented by one of the companies sampled is in the financial and accounting aspects. Companies in the remuneration system do not measure based on working hours but rather measure units of results; branches of results are first broken down into several phases. For example, there is a management phase, a mentoring phase. Several managers appointed by the company will monitor each step of the project, namely labor management, finance, project management, and administration. Each stage has a large output resulting from performance and is given a weight to determine each employee's remuneration. This system is suitable to be applied considering the characteristics of millennial workers who prefer flexibility in their work. Companies with millennial employees need to provide flexibility, flexibility, and comfort to reduce pressure at work and increase employee involvement in various activities, both formal and non-formal [34].

Another strategy used by the company in dealing with millennial workers who tend to choose flexibility in their work is to use their professional management system in the sense that employees work based on output so that personal interaction is not too significant, the company asks employees after the project is finished if you want to stay on the platform 
company. The only permanent employees are project managers; the company does not entrust management to freelancers. The project manager is tasked with monitoring each employee connected through the platform, reminding the deadlines of the work that must be fulfilled; everything is done online to create flexibility and sustainable management. The unique characteristics of the millennial generation and the need for flexibility in working are a challenge for companies, so companies that cannot offer flexibility and space for creativity make it difficult for millennials to be involved in a company [35]. If someone wants to work with an unspecified working time, then he will be hired by the project. If he wants to become a permanent employee or join the team, he must follow the rules of the specified working hours.

To regulate the working hours of the millennial generation, the most crucial thing to apply is discipline. The company thinks that having to do overtime work is not good. Overtime conditions occur because of wrong planning; overtime mirrors failure in planning. There are only two choices, that is Work hard or Work Smart. If you need to work hard, it's better to replace labor with machines, but if work bright is a different matter, you need quality, effective, and efficient human resources in carrying out the work. The company enforces working hours discipline for all employees, but this does not apply to startup founders. There are no weekends and no working days for startup founders because all days are fun for them. However, what needs to be encouraged within the company is the need for work arrangements on weekdays and holidays on holidays. By carrying out work during working hours, regular work will be longer and produce more results compared to marathon work but, in the end, must be rested when workers become sickly; the concept of life is balanced must constantly be reminded of millennial workers. When company leaders can give Millennial Generation employees the freedom to achieve a balanced work-life and personal life, relationship satisfaction with superiors will also increase [14].

The millennial workforce is also doing job crafting by creating programs that can integrate work and personal life to improve their performance [36]. Job crafting has three dimensions: task crafting, relational crafting, and cognitive crafting [37]. Bakker added one more size to job crafting, optimizing job demand and completing tasks more efficiently [38].

\section{Facilitation for Expressing Aspiration}

The company provides the broadest possible platform for millennial generation employees to express their aspirations, innovations, and desires to increase their productivity. Among the efforts made by the company's management is to provide rewards for employees who provide creative and innovative ideas. The company also facilitates millennial generation employees to express their wishes and complaints openly through meeting regularly held events or other media. The conflict resolution factor in the quality of work-life that can be improved is submitting complaints so that leaders can develop negotiating practices in conflict management [29]. Generation Y prefers to deal in solving problems [39]. If the company is deemed unable to provide the right platform for their creative ideas, millennial generation employees will feel dissatisfied and raise turnover intentions [40], [41].

\section{The Company's Efforts To Bridge Across Generations in the Workplace}

Millennial Generation employees are faced with various challenges and demands in the workplace. The first demand is the demand to adapt to senior employees from the previous generation and have different characteristics. The method used by the company to be able to 
bridge the millennial generation with the baby boomer generation and generation $\mathrm{X}$ is to provide an understanding of strategies to be able to communicate and cooperate effectively with each generation. The perception of millennial employees' communication is positively associated with job engagement and organizational commitment; they are generally willing to learn and interact with the age above them [42]. Millennials generally seek support from superiors and prefer open information about the organization's direction [43]. For the baby boomer generation and generation $\mathrm{X}$, education is given to consider the millennial generation to be respected and vice versa. Another way that the company does is to approach it by categorizing generations so that between ages can respect each other and coordinate well.

In the science of team building, there are four stages related to team-building efforts: acquaintance stage, conflict stage, normalization stage, and perform. Millennials who have just joined usually only reach the acquaintance stage; at this stage, millennial generation workers and their superiors have different topics of conversation. Millennial workers prefer to talk about the present while their friends don't, so conflicts usually arise that must be overcome immediately. The millennial generation has a relaxed, friendly, and egalitarian communication style and avoids the dominant communication style full of control. But at the same time, they want guidance and role models. "Ngemong" is the key and way out for the previous generation to communicate effectively with the millennial generation [44]. The frequency needs to be equalized, and it is necessary to explain to millennial workers that they are not playing games. Must sit together, not sit individually, but after the conflict, will come to a period of mutual understanding, which is called the normalization stage. At this stage, parents understand the will of the young, and the young understand the old's choice. The last one just entered the stage of performing. Without getting to this stage, there is no productivity; time will run out in a prolonged period of conflict.

The advantage of a company whose $70 \%$ of employees are under 30 years old is the millennial generation, which means that companies can have extraordinarily productive assets with a record of having a strategy in handling them. Companies must be able to condition workers from the millennial generation not to threaten other workers from the baby boomers and generation X. Still, they must be prepared to manage the millennial generation. Millennials are necessary, but not everything; millennials do not necessarily have an advantage over previous generations; there is no such thing as a miracle, but they must be directed. They may benefit from gadgets and are aware of technology and wide-open horizons, but they lose parental guidance. There are still many millennial children in Indonesia who can be said to have no parents. Often they imitate things from abroad. For example, they should not just imitate startups abroad but need to be adjusted to the conditions in Indonesia. When Indonesia faces the Demographic Bonus, the Millennial generation in Indonesia can become a problem if it is not directed. In Indonesia, the millennial generation in terms of psychology is still categorized as immature. Most of them have been exposed to the global world when they were in junior high school.

\section{The Company's Efforts in Guiding Millennial Generation Workers}

How to foster millennial children to increase company productivity using the stick and carrot system to manage change and challenges. There are two methods which are complex and soft. From the hard side, company regulations must be firm, including the millennial generation. The company did not apply flexible hours in the early stages but first formed discipline in working hours and resting hours. If you violate, the punishment is explicit. If the employee does 
not accept, then the problem is in recruitment; the company must be selective in finding employees willing to be regulated and honest to avoid violations.

The second characteristic is a soft system; there needs to be a knowledge transfer program. Many of the knowledge in the company is the knowledge that is not taught in schools because at school time is very limited. If the company can provide opportunities and facilitate Millennial Generation employees in carrying out career development, Millennial Generation employees will choose to stay in the organization [45]. The company assigns senior employees to train millennial junior workers, such as on-job training or, more precisely, job mentoring, which includes two functions: teaching hard skills and soft skills.

Millennial workers usually have poor soft skills. They should find their weakness in terms of soft skills. In the previous era, it was usually the family environment such as uncle and aunt's parents. Still, nowadays, this does not happen because children, parents, and families are busy with their worlds. Millennials grow up without guidance, and as a result, they do not have adequate soft skills when entering the world of work. Even though they have soft skills, they use a get loss method which means that soft skills are found on the road. Companies can't rely on discovering soft skills like this; companies need to think and ensure how this millennial generation employee can grow.

The most appropriate and essential training for millennial workers is related to discipline. When discipline is established, others will also be awakened. To improve the low work ethic among the millennial generation, it is necessary to develop and improve work ethic through clarity of existing work rules or procedures, accompanied by firm action for those who violate and providing development and training related to work ethic [27]. In addition, the company offers training related to good work ethics, for example, the importance of working hard to achieve success, whether personal or company goals. Here, the leader (supervisor or manager) role model is vital in creating an ethical climate in the organization [46]. Employees who are millennials have high learning agility; the company takes advantage of the potential of the millennial generation, where this generation has a strong desire to grow, learn, is ready for change, and wants flexibility and challenges. With attention to mentoring and coaching from the company's management where employees work, the millennial generation learning agility can help organizations prepare organizations of talents to lead the future [47].

\section{Millennial Generation Employee Recruitment System}

Companies must provide a clear view to prospective millennial workers during the recruitment process. Companies must explain the conditions and capabilities of the company and what millennial job candidates can expect. At the same time, the company explores from prospective employees what they expect and what the future will be like. Some companies are looking for millennials who have a desire to develop their business. For prospective workers who do not want to make a company listed, they will be placed at number one; many companies prioritize millennials who want to create a company or have created a company. This is related to one of the advantages of the millennial generation, which is the entrepreneurial spirit. Millennial leadership needs to encourage innovation, creativity, and the entrepreneurial spirit of the new age. All channels of invention, creativity, and entrepreneurship must be well designed and concrete [48].

Millennials, in general, when they are looking for work, first look for vacancies from the internet, then look in newspaper advertisements, then look on the company website, lastly from friends. Meanwhile, in that company, if there are vacancies they look for from friends first, then to HRD, post the last advertisement, so that excellent job vacancies are rarely advertised. 
The millennial generation needs to be directed and given career consultations on getting an excellent job by not changing jobs and building good relationships with superiors. The question is, what if the company is deemed not to make its employees grow? That means prospective workers have to choose from the beginning whether the company to be selected allows them to grow or not. Often future workers decide to work in the company without careful consideration, just based on reviews rather than being unemployed. The company is also like that, often accepting half-hearted workers to stay in the company without a significant contribution. So when a company does recruitment, it must be honest with prospective employees; if a small company has to say small, see if the prospective employee can help the company become big. But if the company that will recruit employees is large, they will prefer people who are motivated to get achievements to help the company become even more significant.

Errors often occur during recruitment, either by the company or by the applicant. Many companies are also dishonest with applicants. It is necessary to educate companies to be transparent from the start. Still, some companies care and are concerned that they don't want just to hire \& fire and pay attention to their company's growth by paying attention to a sound recruitment system.

\section{Conclusion}

In dealing with workers who come from the millennial generation, companies must have a special strategy so that they can explore their potential to be able to increase their work productivity. Companies must apply discipline rules to millennial workers without any offers, because they still need to shape themselves, they still need time to learn and build discipline within themselves. Companies must also be selective in the recruitment process if they want to increase productivity. To facilitate the quality improvement of millennial workers, companies must have a knowledge transfer program for the development of millennial workers so that they can use their potential optimally. Another facility that must be provided by the company is to provide a platform for the millennial generation to express their aspirations so that they can explore their innovative and creative ideas. To be able to create a conducive work environment, the company must bridge communication and coordination between the millennial generation and previous generations so that a harmonious relationship can be created.

\section{References}

[1] B. P. Statistik, Statistik Gender Tematik: Profil Generasi Milenial Indonesia. Jakarta: Kementerian Pemberdayaan Perempuan dan Perlindungan Anak, 2018.

[2] Y. Yembise and Suhariyanto, "Statistik Gender Tematik: Profil Generasi Milenial Indonesia," Jakarta, 2018

[3] A. W. Winny and E. K. Jimmy, "Hubungan Person Job-Fit dengan Keterlibatan Kerja pada Karyawan Generasi Milenials di Perusahaan X," Psychopreneur J., vol. 4, no. 2, pp. 90-99, 2020.

[4] S. Fahreza, L. Kartika, and A. Sayekti, "Analisis faktor engagement karyawan generasi milenial pada perusahaan berbasis ekonomi kreatif," J. Manaj. Indones., vol. 19, no. 1, pp. 56-70, 2019.

[5] "Generasi Milenial dan Era Industri 4.0," detik.com, 2018. https://news.detik.com/kolom/d3981811/generasi-milenial-dan-era-industri-40 (accessed Jul. 10, 2021).

[6] J. M. Twenge, "A review of the empirical evidence on generational differences in work attitudes," J. Bus. Psychol., vol. 25, pp. 201-210, 2010. 
[7] A. Bencsik, C. G. abriella Horváth, and T. Juhász, "Y and Z Generation at Workplaces," J. Compet., vol. 8, no. 3, pp. 90-106, 2016.

[8] P. Ju Chen and C. Youngsoo, "Generasi Differences In Work Veles : A Study of Hospitality Management," Int. J. Contemp. Hosp. Manag., vol. 20, no. 6, 2008.

[9] A. Susi, "Tantangan Perusahaan Mengelola Perbedaan Generasi Karyawan," ESENSI J. Manaj. Bisnis, vol. 22, no. 376-382, 2019.

[10] B. Jora R and S. Khan, "Motivating Multigenerational Human Resource," Int. J. Organ. Behav. Manag. Perspect., vol. 3, no. 4, pp. 2279-0950, 2014.

[11] J. Benson and M. Brown, "Generations at work: Are there differences and do they matter?," Int. J. Hum. Resour. Manag., vol. 22, no. 9, pp. 1843-1865, 2011.

[12] V. . Anantatmula and B. Shrivastav, "Workforce, Evolution of Project Teams for Generation Y Workforce," Int. Manag. Proj. Bus., vol. 51, pp. 9-2 6, 2012.

[13] A. Glass, "Understanding generational differences for competitive success," Ind. Commer. Train., vol. 39, pp. 98-103, 2007.

[14] K. W. Smola and C. D. Sutton, "Generational differences: Revisiting generational work values for the new millennium," J. Organ. Behav., vol. 23, pp. 363-382, 2002.

[15] Y. M. Rita, "Perbedaan Nilai-Nilai Kerja Generasi Baby Boomer, Generasi X Dan Generasi Y," J. Ekobis Ekon. Bisnis Manaj., vol. 11, no. 1, pp. 79-91, 2021.

[16] A. D. Nindyati, "Pemaknaan Loyalitas Karywan pada Generasi X dan Generasi Y, Studi pada karyawan di Indonesia," J. Psychol. Sci. Prof., vol. 1, no. 1, 2017.

[17] J. Meier, A. F. Austin, and M. C. Crocker, "Generation Y in the Workforce: Managerial Challenges," J. Hum. Resour. Adult Learn., vol. 6, no. 1, pp. 68-78, 2010.

[18] H. Erkutlu, "The Moderating Role Of Organizational Culture In The Relationship Between Organizational Justice And Organizational Citizenship Behaviors.," Leadersh. Organ. Dev. J., vol. 32, no. 6, pp. 532-554., 2016.

[19] Ervina, "Prinsip dan Budaya Kerja Generasi Y yang Harus Diketahui," Insight Talenta, 2019. talenta.co/blog/insight-talenta/prinsip-dan-budaya-kerja-generasi-y/ (accessed Jul. 09, 2021).

[20] Cole, Gene, S. Richard, and L. Laurie, "The Debut of Generation Y in the American Workforce," J. Bus. Adm. Online, vol. 1, no. 2, 2002.

[21] Blain, "The Millennial Tidal Wave: Five Elements That Will Change the workplace of Tomorrow," J. Qual. Assur. Inst., vol. 22, no. 2, pp. 11-13, 2008.

[22] H. Fatimah, A. H. Dharmawan, E. Sunarti, and M. J. Affandi, "Pengaruh Faktor Karakteristik Individu dan Budaya Organisasi terhadap Keterikatan Pegawai Generasi X dan Y,” J. Apl. Manaj., vol. 13, no. 3, 2015.

[23] Brown, "Generation Y in The Workplace," J. HR Manag., 2008.

[24] H. A. B. Amin, "5 Ciri Kerja Para Milenial yang Harus Diperhatikan Perusahaan," Pantau.com, 2019. https://www.pantau.com/topic/infografis/infografis-5-ciri-kerja-para-milenial-yang-harusdiperhatikan-perusahaan (accessed Jul. 09, 2021).

[25] R. Zeni and G. Janti, "Hubungan Job related Factors terhadap Work life Balance dan Kepuasan Kerja pada Pekerja Generasi Milenial,” J. Sains Dan Seni ITS, vol. 8, no. 2, pp. 2337-3520, 2019.

[26] "Infografis: Bagaimana Potret Millennial di Dunia Kerja?," 2017. https://kumparan.com/kumparannews/infografis-bagaimana-potret-millennial-di-dunia-kerja (accessed Jul. 09, 2021).

[27] A. W. Seta, N. Rosi, and P. A. Aisyah, "Gambaran Etos Kerja pada Karyawan Generasi Milenial di PT X,” ISOQUANT J. Ekon. Manaj. dan Akunt., vol. 4, no. 2, pp. 186-197, 2020.

[28] T. Angeline, "Managing generational diversity at the workplace: Expectations and perceptions of different generations of employees," African J. Bus. Manag., vol. 5, no. 2, pp. 249-255, 2011.

[29] D. P. Amalia and K. Lindawati, "Analisis Pengaruh Budaya Organisasi Dan Kualitas Kerja Terhadap Keterikatan Pegawai Generasi Y,” J. Ekobis Ekon. Bisnis Manaj., vol. 10, no. 2, pp. 145-161, 2020.

[30] A. Somech and A. Drach-Zahavy, "Exploring Organizational Citizenship Behaviour From An Organizational.," J. Occup. Organ. Psychol., vol. 77, pp. 281-298, 2004.

[31] F. A. Trapero, L. E. Villa-Castaño, J. C. V Parra, and J. D. la G. García, "Differences on self- 
perception of organizational pride and loyalty in Millennial \& Generation X, considering gender and seniority variables," BEH Bus. Econ. Horizons, vol. 13, no. 2, pp. 270-286, 2017.

[32] S. C. Bushardt, M. Young, and A. Bari, "Transitioning to management: Challenges and opportunities for the millennial generation," J. Bus. Divers., vol. 18, no. 1, pp. 9-16, 2018.

[33] F. B. B. Ahmad and R. Arrafiqur, "Pengaruh Work Life Balance Dan Budaya Organisasi Terhadap Employee Engagement Pad Generasi Milenial Di Pt. Gunung Sawit Mas Desa Rantau Panjang Kecamatan Tambusai Kabupaten Rokan Hulu," HIRARKI J. Ilm. Manaj. dan Bisnis, vol. 2, no. 3, pp. 54-62, 2020

[34] A. D. P. Taufik, A. P. Nabella, and Q. Oom, "Stres Kerja, Keterlibatan Kerja dan Intensi Turnover pada Generasi Milenial," Psikostudia J. Psikol., vol. 9, no. 2, pp. 154-163, 2020.

[35] Akhavan, A. R. A. Sarraf, M. Abzari, A. N. Isfahani, and S. Fathi, "Generational differences in job engagement: A case study of an industrial organization in Iran," Industrial and Commercial training., 2017.

[36] F. R. Akhmad, "Factors That Cause Work Engagement in the Millennial Performance in BUMN: Faktor- Faktor Penyebab Work Engagement pada Angkatan Kerja Millennial di BUMN," in Proceeding of The ICECRS, 2020, pp. 1-8.

[37] A. Wrzesniewski and J. . Dutton, "Crafting a job: revisioning employees as active crafters of their work," 2001

[38] A. . Bakker, S. . Albrecht, and M. . Leiter, "Key questions regarding work engagement," Eur. J. Work Organ. Psychol., 2011.

[39] S. Mukundan, D. Mukundan, and K. P. Sarawathyamma, "A study on the conflict resolution styles of generation Y students in the Indian context," Int. J. Glob. Bus., vol. 6, no. 1, 2013.

[40] D. Oktariani, V. H. Aida, and S. Dadang, "Kepuasan Kerja Generasi X dan Generasi Y terhadap Komitmen Kerja di Bank Mandiri Palembang," J. Apl. Bisnis dan Manaj., vol. 3, no. 1, 2017.

[41] R. Nurhasan, "Kepuasan Kerja dan Loyalitas Generasi Y,” J. Wacana Ekon., vol. 17, no. 1, pp. 13-23, 2017.

[42] J. Walden, E. H. Jung, and C. Y. K. Westerman, "Employee communication, job engagement, and organizational commitment: A study of members of the Millenial Generation," J. Public Relations Res., vol. 29, no. 3, pp. 73-89, 2017.

[43] K. K. Myers and K. Sadaghiani, "Millenials in the workplace: A communication perspective on millennials organizational relationships and performance," J. Bus. Psychology, vol. 21, pp. 225238, 2010.

[44] C. C. Lintang and N. I. Prinisia, "Generasi Z dan Pemeliharaan Relasi Antar Generasi dalam Perspektif Budaya Jawa,” J. Komun. Dan Kaji. Media, vol. 4, no. 2, pp. 84-105, 2020.

[45] M. Aruna and J. Anitha, "Employee retention enablers: Generation Y employees," SCMS J. Indian Manag., vol. 12, no. 3, pp. 94-103, 2015.

[46] Y. S. Silverius and N. Rosi, "Pengaruh Budaya Organisasi terhadap Employee Engagement dengan Work Ethic (Hard Work) sebagai Variabel Moderator: Studi Kasus pada Karyawan Generasi Milenial di PT X," Mind Set, vol. 11, no. 1, pp. 46-54, 2020.

[47] J. Devi and K. Puspitasari, "Learning Agility Pada Karyawan Generasi Milenial Di Jakarta," J. Muara Ilmu Sos. Humaniora, dan Seni, vol. 3, no. 1, pp. 187-199, 2019.

[48] Y. P. Ni Putu Depi and K. Dedi, "Kepemimpinan Ideal Pada Era Generasi Milenial,” Transform. J. Manaj. Pemerintah., vol. 10, no. 1, pp. 73 - 84, 2018. 